\title{
UMA ANÁlise dos Mitos QUe enVolvem os aLUNOS COM ALTAS habilidades: a REALIDADE DE UMA ESCOLA DE SANTA MARIA/RS
}

\author{
AN ANALYSIS OF THE MYTH THAT INVOLVES HIGH ABILITY STUDENTS: THE \\ REALITY OF A SCHOOL FROM SANTA Maria/RS
}

\author{
Andréia Jaqueline Devalle RECH ${ }^{1}$ \\ Soraia Napoleão FREITAS²
}

\begin{abstract}
RESUMO: no Brasil, ainda existem poucas pesquisas sobre a temática das altas habilidades, suscitando, assim, maiores discussões no campo da educação, em particular, da educação especial. Diante disso, al guns mitos ou idéias equivocadas perpassam a trajetória acadêmica dos alunos com altas habilidades. Isso se deve ao fato do desconhecimento, por parte de alguns professores, sobre como reconhecer e estimular as habilidades desses alunos. N este artigo são apresentados os resultados de uma pesquisa proposta para investigar se os mitos que envolvem os alunos com altas habilidades prevalecem na concepção dos docentes do ensino fundamental de uma escola da rede pública estadual de Santa Maria/ RS. Dez professoras do turno da tarde, que lecionam de $1^{\underline{a}}$ à $4^{a}$ série, participaram da pesquisa. $O$ instrumento definido para a coleta dos dados foi a entrevista semiestruturada, aplicada individualmente em um ambiente reservado. Para o registro dos dados foi utilizado gravador, mediante autorização prévia das entrevistadas. A análise de conteúdo foi utilizada como forma de "leitura" das falas dos sujeitos partici pantes da pesquisa. Como resultado, à incidência dos mitos nas entrevistas das dez participantes, foi constatado que a professora " $A$ " pode ser observada em $60 \%$ dos mitos citados, as demais não ultrapassaram a $20 \%$. Esse fato pode ser explicado, pois essa professora não participou da pesquisa desenvolvida na escola nos anos de 2002 e 2003. As considerações finais apontam para a importância da conscientização dos professores que atuam em sala de aula regular, para que eles saibam identificar, atender e/ ou encaminhar alunos com características de superdotação para um atendimento especializado.
\end{abstract}

PALAVRAS-CHAVE: mito, altas habilidades, educação especial.

ABSTRACT: in Brazil, there is little research about the thematic of high abilities causing larger discussions in the Education Field, particularly, in the Special Education Field. Consequently, some myth or erroneous ideas pass along the academic trajectory of high ability students. This happens due to the lack of knowledge, partly from some teachers, about ways of identifying and stimulating thetalents of thesestudents. This article presents results of a research proposed to investigate if the myth that involves students showing high abilities prevails in the conceptions of elementary school teachers from a public school of Santa Maria/ RS. Ten teachers from afternoon shift, who teach from $1^{\text {st }}$ to $4^{\text {th }}$ grades, participated in this research. The defined instrument to the data collecting was the semi-structured interview that was applied individually in a reserved environment. A tape recorder was used to record the data upon previous authorization of the interviewed teachers. The content analysis was used as a way of "reading" the participants talking. As a result from the incidence of myth in the interviews with ten participants, it was noted that the teacher " $A$ " can be observed in $60 \%$ of the mentioned myth while the others did not surpass $20 \%$. This fact can be explained because that teacher did not participate in the research developed in the school in 2002 and 2003. The final considerations point out the importance of awareness from teachers that work in a regular classroom so that they can identify and direct students with giftedness characteristics to a specialized service.

KEYWORDS: myth; high abilities; special education.

${ }^{1}$ Mestranda do Programa de Pós-graduação em Educação - Linha de Educação Especial - UFSM; Bolsista PROESP/ CAPES andi@smail.ufsm.br

2 Profa. Dra. do Departamento de Educação Especial - UFSM e orientadora da pesquisa soraianf@fatecnet.ufsm.br - Integrantes do Grupo de Pesquisa do CN Pq- Educação Especial: Interação e Inclusão Social 


\section{IINTRODUÇão}

Quando se fala em Educação Especial, pensa-se, num primeiro momento, que ela está direcionada apenas a alunos com deficiência mental, auditiva, visual ou física. Porém, é esquecido que, assim como essas crianças, também os alunos com altas habilidades necessitam de um atendimento especializado.

Diante disso, em 1999, iniciamos um projeto de pesquisa intitulado: "Educandos superdotados/ tal entosos/ portadores de al tas habilidades - Da identificação à orientação". Essa pesquisa teve como objetivo identificar alunos com altas habilidades indicados pelos professores das séries iniciais do ensino fundamental da rede estadual e particular de Santa Maria/ RS, bem como conscientizar os pais destes educandos sobre a importância de valorizar talentos e auxiliar os professores no que fosse possível.

Com o andamento da pesquisa ao longo de cinco anos, algumas situações foram sendo constatadas. Entreelas o despreparo profissional, pois, como esses professores não tiveram acesso a estudos referentes a tal temática durante sua formação acadêmica, não se sentiam preparados para trabalhar com o aluno com altas habilidades. Em conseqüência, eles encontravam muitas dificuldades em, primeiramente, identificar os alunos e, posteriormente, saber como atendêlos.

Diante disso, nas palestras de conscientização e esclarecimentos que foram realizadas em dez escolas, nove estaduais e uma particular, percebemos que determinados mitos em relação aos al unos com al tas habilidades têm persistido no senso comum de alguns professores. Esses faziam referências ao aluno com altas habilidades como sendo um sujeito bem ajustado, que por si só dá conta da sua educação, não necessitando de uma educação especial. Sobre esse assunto, Extremiana (2000, p. 102), constata que: “[...] sól o por ser superdotados tienen el éxito asegurado; no necesitan ayuda ni en la escuela ni en el hogar porque triunfan de forma natural, sin interferencias". 3 Sendo assim, a partir das falas de alguns professores, foi possível perceber concepções equivocadas, também alimentadas pela sociedade em geral a respeito do que seja um aluno com al tas habilidades.

Outro mito se refere aos alunos como "globalmente superdotados" 4 . Ou seja, apresentam uma habilidade superior em todas as áreas do conhecimento, sendo inadmissível que apresentem alguma dificuldade de aprendizagem em qualquer campo do saber ou do fazer. Diante desses mitos propagados por professores, deduzimos que os alunos com altas habilidades constituem uma parcela da população escolar que não é facilmente reconhecida pelos professores.

\footnotetext{
${ }^{3}$ Tradução livre: “[...] somente por serem superdotados têm êxito assegurado; não necessitam de ajuda nem da escola nem da família porque triunfam de forma natural, sem interferências".

${ }^{4}$ Este termo é utilizado pela pesquisadora americana Ellen Winner (1998) e refere-se às crianças globalmente superdotadas como possuidoras de um poder intelectual, o que as levaria a serem superdotadas em todas as áreas do conhecimento.
} 
Ou ainda, em alguns casos, esses alunos são vistos como uma elite, CDF, tantos outros rótulos que têm sido perpetuados pela comunidade escolar, tanto pelos professores quanto pelos colegas.

Portanto, torna-se necessário o desenvolvimento de pesquisas na área das altas habilidades, divulgando a necessidade da identificação desses alunos. À medida que os professores os reconhecerem como crianças com necessidades educacionais especiais e desmitificarem seus conceitos referentes às altas habilidades, haverá uma maior probabilidade de que tais alunos tenham seus direitos educacionais real mente cumpridos.

Nessesentido, esta pesquisa teve como propósito investigar se os mitos que envolvem os alunos com altas habilidades prevalecem na concepção dos docentes do ensino fundamental de uma escola da rede pública estadual de Santa Maria/ RS.

É importante ressaltar que, das dez docentes que participaram desta pesquisa, nove tiveram acesso a palestras informativas durante a execução do projeto Educandos superdotados/talentosos/portadores de altas habilidades - Da identificação à orientação.

\section{Quem É a PesSoa com altas habilidades?}

A temática das altas habilidades tem sido objeto deestudo dediferentes pesquisadores, tanto em nível nacional quanto internacional. Assim, diversos conceitos são utilizados para definir quem é a pessoa com altas habilidades. N em os próprios pesquisadores chegaram a um consenso em relação à terminologia mais apropriada para ser utilizada.

No Brasil, em 1995, a partir das Diretrizes Gerais para o A tendimento Educacional aosAlunos Portadores deAltas Habilidades/ Superdotação eTalentos, estabelecidas pela Secretaria de Educação Especial do Ministério da Educação e Desporto, foi proposta a seguinte definição:

Altas habilidades referem-se aos comportamentos observados e/ ou relatados que confirmam a expressão de 'traços consistentementesuperiores' em relação a uma média (por exemplo: idade, produção ou série escolar) em qualquer campo do saber ou do fazer. Deve-se entender por 'traços' as formas consistentes, ou seja, aquelas que permanecem com freqüência e duração no repertório dos comportamentos da pessoa, de forma a poderem ser registradas em épocas diferentes e situações semelhantes. (BRA SI L, 1995a, p. 13).

É importantedestacar queessa defini ção engl oba os comportamentos/ traços acima da média, quando observados e comparados aos demais, aliados à permanência e duração destes. N esse mesmo documento, o MEC (BRASIL, 1995a, p. 14-15) aponta seis tipos de superdotação: intel ectual, social , acadêmico, criativo, psicomotricinestésico e talentos especiais. 
Assim, no decorrer desse trabalho, utilizaremos o termo altas habilidades para se referir a esta parcela da população brasileira que, segundo a Organização Mundial da Saúde (OMS), constitui cerca de 3\% a 5\%. Entretanto, seremos fiéis à nomenclatura que os diferentes autores adotarem para se referir a esses sujeitos.

Deve-se ressaltar queesta porcentagem estabelecida pela OMSengloba apenas os sujeitos identificados por meio dos testes de QI, com escores acima de 140. Sobre esse assunto, Winner (1998, p. 15) afirma que: “os testes de QI medem uma estreita gama de habilidades humanas, principalmente facilidade com linguagem e número. Há poucas evidências de que superdotação em áreas nãoacadêmicas, como artes ou música, requeiram um QI excepcional". Ou seja, há uma parcela da população que não está incluída nestas estatísticas, já que os testes padronizados não privilegiam áreas mais subjetivas, por exemplo, habilidades cinestésicas.

No ano de 1999, a SEESP (Secretaria de Educação Especial) do MEC publicou um manual sobre superd otação etal ento, visand o fornecer subsídios para os professores. Assim, definiram que: "superdotação caracteriza-se pela el evada potencialidade de aptidões, talentos e habilidades, evidenciadas pelo alto desempenho nas diversas áreas de atividade" (BRASIL, 1999a, p. 35). Além disso, a constância dessas aptidões e um nível significativo de desempenho devem ser observados com o passar do tempo.

\subsection{IDENTIFICANDO E CARACTERIZANDO OS ALUNOS COM ALTAS HABILIDADES}

A definição adotada pelo Brasil para caracterizar os alunos com altas habilidades é a mesma que foi proposta pelo Departamento de Saúde, Educação e Bem-estar dos Estados Unidos, em 1972. Dessa forma, é considerado portador de altas habilidades aquele que se destaca por elevado desempenho e/ ou expressivas potencialidades relacionadas com os seguintes aspectos, isolados ou combinados: "Capacidade intelectual; A ptidão acadêmica específica; Pensamento criador ou produtivo; Capacidade de liderança; Talento especial para artes visuais, artes dramáticas e música e Capacidade psicomotora" (ALENCAR; FLEITH , 2001, p. 56).

O processo de identificação dos alunos com altas habilidades não é algo simples. Em decorrência disso, o Ministério da Educação e Desporto e a Secretaria da Educação Especial publicaram, em 1995, os Subsídios para Organização e Funcionamento de Serviços de Educação Especial - Á rea de Altas $\mathrm{H}$ abilidades. Nesse documento, al guns procedimentos foram apresentados para identificar as crianças com altas habilidades, ente eles:

avaliação realizada por professores, especial istas e supervisores; percepção de resultados escolares superiores aos demais; auto-avaliação; aplicação de testes individuais, coletivos ou combinados e demonstração de habilidades superiores em determinadas áreas. (BRASIL, 1995b, p. 23) 
Ainda, a avaliação desses alunos deve ser feita por uma equipe interdisciplinar. Extremiana (2000, p. 102) reforça a necessidadedereunir um maior número de fontes possíveis para a identificação dos alunos com altas habilidades. Ela observa que: este enfoque, por tanto, se basa no sólo en los tests de rendimiento y de capacidad, sino también en la información que es proporcionada por profesores, padres y compañeros, así como en las actividades y trabajo diario de los alumnos. Dessa forma, os testes padronizados, como, por exemplo, os de QI, não podem ser vistos como única fonte de identificação, pois sabe-se que esses testes valorizam áreas como a lógi co-matemática ea lingüística, não contemplando as demais habilidades. O que leva "[...] a tornar essa identificação mais difícil e, ao mesmo tempo mais urgente, é a multiplicidade de habilidades, interesses e talentos existentes nesse alunado" (BRASIL, 1995b, p. 24). Assim, se outros aspectos, como, por exemplo, motivação, criatividade, não forem considerados, há uma grande probabilidade de muitas habilidades não serem identificadas.

Sobre esse assunto, Alencar e Fleith (2001, p. 52-53) afirmam que:

Sabemos que tradicional mente os testes de inteligência não medem al gumas operações presentes no pensamento criativo, eassim um indivíduo pode passar despercebido pelos testes de inteligência, apesar de ter um potencial criativo superior. O mesmo ocorrecom diversos tipos dehabilidades, que podem passar despercebidas se forem considerados apenas resultados em testes de inteligência.

Nesse sentido, mensurar a inteligência pretendendo obter uma avaliação estática e definitiva, atualmente, não é o mais aceitável. Então, como medir o nível decriatividade e motivação desses al unos em um teste psicométrico?

É importantesalientar queas crianças com al tas habilidades apresentam perfis heterogêneos, inclusive se comparadas entreelas mesmas. Para exemplificar essa afirmação, Guenther (2000, p. 45) diz que: "sem dúvida elas não são iguais entresi, mas seigualam a essenível deserem diferentes dos outros". Como qualquer criança, tais al unos também apresentam particularidades. A ssim, as características anteriormente citadas podem ou não fazer parte desses indivíduos.

Fatores como a personalidade, o ambiente sócio-cultural e o próprio desenvolvimento humano contribuem para queas pessoas sejam constituídas como seres únicos (que são). Além disso, a criança com altas habilidades:

[...] é primeiramente uma criança essencialmente igual às outras crianças. Portanto, muitos dos seus comportamentos e características são atributos próprios de sua faixa etária e estágio de desenvolvimento em que se encontra, e vão existir nas outras crianças, como seres humanos que são. (GUENTHER, 2000, p. 44)

Assim sendo, propiciar um ambiente acolhedor, em casa e na escola, oferecer a estas crianças atenção, amor, compreensão, entre outros "ingredientes", são de extrema importância para que el as se desenvolvam de forma sadia. 


\section{Mito - SUA RELAÇão COM AS ALTAS HABILIDADES}

Alguns pesquisadores brasileiros, como Alencar e Fleith (2001), Guenther (2000) e o MEC (BRA SIL, 1999a), eestrangeiros, como a americana Winner (1998), e a espanhola Extremiana (2000), têm abordado em suas publicações os mitos e crenças que envolvem as crianças com altas habilidades.

Historicamente, os mitos (do grego mфthos, 'fábula')5 surgem para tentar compreender as diferentes situações que os seres humanos presenciavam que, em alguns casos, eram incompreensíveis. Isso porque, o que não podia ser confirmado pela ciência era denominado de bruxaria, castigo, entre outros.

Pérez (2003, p. 47) cita que “o sentimento de amor/ ódio em relação às $\mathrm{PAH}^{6}{ }^{6}$ vislumbrava-se no Renascimento, quando os 'gênios' eram alvo delee dos mitos que a sociedade criara para estas pessoas". Com isso, as pessoas com altas habilidades têm sua identidade distorcida, o que leva à dificultar sua real "visualização". Tudo isso, pois para uma parcela da sociedade elas não passam de mitos, o quedificulta sua identificação e, conseqüentemente, seu encaminhamento para um atendimento especializado, que por vezes é questionado e visto como desnecessário.

Os mitos também podem ser entendidos como uma "representação coletiva muito simplista e muito esteriotipada, comum a um grupo de indivíduos" (RUSS, 1994, p. 187). Assim, os mitos surgem no imaginário popular como forma de tentar compreender os mistérios de natureza física, sobrenatural, mas também produtos de determinadas circunstâncias históricas e sociais.

Além disso, segundo o Dicionário Aurélio Eletrônico séc. XXI, (FERREIRA, 1999), "um mito pode ser entendido como uma imagem simplificada e ilusória de pessoa ou de acontecimento, elaborada ou aceita pelos grupos humanos, representando um significativo papel em seus comportamentos". Dessa forma, um mito que esteja relacionado às altas habilidades dificulta, entre outros aspectos, a concretização de programas (direcionados à estes al unos) que tenham por objetivo enriquecer os conteúdos trabal hados na escola.

Por fim, após abordar os conceitos sobre os mitos, na visão de diferentes autores, fica evidente que os mitos somente são verbalizados devido ao desconhecimento ou distorção queas pessoas usam para explicar aquilo queignoram.

\section{Desenvolvimento dA PESQUisa}

Para a realização deste estudo, utilizamos a pesquisa descritiva, com análise qual itativa, com características deestudo decaso. Pois, deacordo com M inayo (2000, p. 22), “[...] a abordagem qual itativa aprofunda-se no mundo dos significados

\footnotetext{
${ }^{5}$ Dicionário Aurélio Eletrônico séc. XXI, (FERREIRA, 1999).

${ }^{6}$ Pessoas com Altas Habilidades (grifo nosso).
} 
das ações e relações humanas, um lado não perceptível enão captável em equações, médias eestatísticas". A pesquisa proposta vai ao encontro dessa idéia, pois pretende obter informações sobre as atitudes e pensamentos de sujeitos, o que não é possível ser simplesmente avaliado por um número. Dentre as pesquisas que são descritivas o estudo decaso foi sel ecionado, já que "estes estudos têm por objetivo aprofundarem a descrição de determinada realidade" (TRIVIÑOS, 1987, p. 110).

\section{SUJEITOS DA PESQUISA}

Dentre as escolas do ensino fundamental da rede pública estadual de Santa Maria/ RS, uma foi selecionada para compor o corpus pesquisado. O critério utilizado para a escolha dessa escola foi ter participado do projeto de pesquisa Educandos superdotados/talentosos/portadores de altas habilidades - D a identificação à orientação, realizado em nove escolas, e ter identificado, por meio de entrevistas, o maior número de alunos com altas habilidades. Os professores que participaram de tal pesquisa tiveram acesso a palestras informativas a respeito desses alunos. Assim sendo, partimos do pressuposto de que já tinham adquirido um conhecimento prévio sobre a temática. Mesmo assim, buscamos investigar se os mitos correntes que envolvem tais alunos ainda persistem na concepção dos docentes.

A pós a definição da escola participante, as pesquisadoras dirigiram-se atéa instituição efoi feito o conviteaos docentes-sujeitos a participarem da pesquisa. Os professores tiveram total liberdade para o aceitarem ou não, ainda que tivesse sido frisada a importância de estudos na área das altas habilidades, pois esses alunos estão matriculados no sistema regular de ensino e, na maioria das vezes, não são identificados e acabam sendo rotulados como indisciplinados, desinteressados, entre outros.

Dessa forma, participaram dez professoras de uma escola da rede pública estadual de Santa Maria/ RS, que lecionavam entre 1a e $4^{a}$ série, no turno

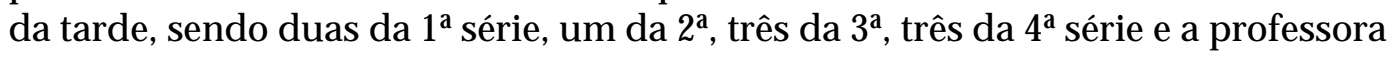
de educação física, todas do sexo feminino. Deve-se ressaltar que duas professoras não mostraram interesse em participar da pesquisa, alegando falta de tempo.

Das dez docentes participantes, novedelas receberam informação sobre a temática das al tas habilidades, euma não. Essas informações, como já mencionado, referem-seao projeto E ducan dos superdotados/ talentosos/ portadores dealtas habilidades - D a identificação à orientação, realizado na escola nos anos de 2002 e 2003.

\section{INSTRUMENTOS E PROCEDIMENTOS}

O instrumento utilizado para a coleta dos dados foi a entrevista semiestruturada, que é entendida como:

[...] aquela que parte de certos questionamentos básicos, apoiados em teorias e hipóteses, queinteressamà pesquisa, eque, em seguida, oferecem amplo campo 
de interrogativas, fruto de novas hipóteses que vão surgindo à medida que se recebem respostas do informante (TRIVIÑ OS, 1987, p. 146).

Por se tratar de uma entrevista semi-estruturada, optamos por iniciála com perguntas previamente definidas. Para isso, tivemos como base a classificação que Pérez (2003) organizou, a qual traz uma compilação dos mitos que a literatura apresenta e dividiu-os em sete categorias. Assim, as categorias propostas por Pérez foram consideradas como um roteiro para elaborar as perguntas que foram respondidas pelas professoras. No entanto, conforme foram sendo respondidas, sentiu-se a necessidade de acrescentar novos questionamentos.

A entrevista foi utilizada como técnica de coleta de dados, pois tem como objetivo um contato mais próximo com o entrevistado, já que "[...] na entrevista a rel ação que secria é de interação, havendo uma atmosfera de influência recíproca entre quem pergunta equem responde", ou ainda, "[...] a entrevista ganha vida ao seiniciar o diálogo entreo entrevistador eo entrevistado" (LÜDKE; ANDRÉ, 1986, p. 34). Por tudo isso, a entrevista é considerada uma das principais técnicas utilizadas nas pesquisas que se referem à educação.

A entrevista semi-estruturada foi aplicada na própria escola, em um ambiente reservado, de forma individual. Na mai oria das vezes, o procedimento foi realizado na sala de professores ou na própria sal a de aula em quea entrevistada era regente. O horário foi previamente agendado, ficando a cargo de cada uma delas escolher o momento em que tivesse maior disponibilidade para responder às perguntas. O horário "da aula deEducação Física” foi o mais utilizado, uma vez que as crianças tinham uma professora específica para ministrar tal disciplina; então, a professora regentetinha cerca de quarenta minutos disponíveis. As demais professoras escolheram responder às perguntas ao final do recreio, antes das reuniões pedagógicas, que sempre eram realizadas às quartas-feiras. O tempo disponível foi cerca de trinta minutos.

Durante a realização das entrevistas, o gravador foi utilizado para registrar as falas das professoras. Isso ocorreu mediante autorização prévia das entrevistadas, que assinaram um Termo de Consentimento Livre e Informado, autorizando a pesquisadora a fazer uso de suas fal as para análise e discussão dos dados.

A pós o término das entrevistas, o conteúdo registrado foi transcrito, mantendo-se fiel o que foi dito pelas professoras.

Para análise dos dados, foi utilizada a análise de conteúdo como forma de leitura do que foi dito pelos sujeitos da pesquisa. A análise de conteúdo é entendida como:

Um conjunto de técnicas de análise das comunicações, visando obter, por procedimentos sistemáticos e objetivos de descrição do conteúdo das mensagens, indicadores (quantitativos ou não), que permitam a inferência de conhecimentos relativos às condições de produção/ recepção (variáveis inferidas) das mensagens. (BARDIN, 1977, p. 42) 
Sendo assim, a partir da fala das professoras, foram considerados os aspectos qualitativos e não quantitativos.

De acordo com Bardin (ibid., p. 95), há três etapas que compreendem a análise de conteúdo: pré-análise, exploração do material e o tratamento dos resultados, inferência e interpretação.

A pré-análise diz respeito à organização do material coletado, ou seja, inicial mente o pesquisador realiza uma leitura geral desse conteúdo. N a exploração do material, é realizado um estudo mais aprofundado do conteúdo previamente extraído. Por fim, vem a etapa do tratamento dos resultados obtidos ei interpretação que está amparada nos materiais coletados desde a primeira etapa e resulta da reflexão e intuição do pesquisador após as leituras prévias do conteúdo.

Realizados esses passos, o pesquisador chega à categorização que "é uma operação de classificação de elementos constitutivos de um conjunto, por diferenciação e, seguidamente, por reagrupamento segundo o gênero (analogia), com os critérios previamente definidos" (BARDIN, 1977, p. 117).

As categorias dos mitos em questão já estavam previamente defini das por Pérez, a saber: Mitos sobre constituição; Mitos sobre distribuição; Mitos sobre identificação; Mitos sobreníveis ou graus deinteligência; M itos sobre desempenho; Mitos sobre conseqüências; Mitos sobre atendimento. (2003, p. 48-57). Dos sete mitos, apenas o mito que diz respeito aos níveis ou graus de inteligência não foi utilizado na pesquisa, já que esse mito foi agrupado ao mito sobre desempenho, que diz respeito aos alunos com al tas habilidades o esteriótipo de al uno nota 10, que apenas é identificado como tal por ter um Q.I excepcional, entre outros.

Então, após a transcrição das falas das entrevistadas, realizamos um agrupamento daquilo quenão se parecia, para depois agrupar por analogias. Dentre as sete categorias, após realizar os passos que envolvem a análise de conteúdo, seis foram escolhidas.

Além disso, as categorias podem ser estabeleci das por quatro critérios: semântico, sintático, léxi co eexpressivo (BARDIN , 1977, p. 118). Para este trabalho, utilizou-se como critério o modo léxico que "classifica as palavras segundo o seu sentido, com emparelhamento dos sinônimos e dos sentidos próximos".

Para cada categoria, Pérez (2003) estabeleceu indicadores. Assim, as categorias foram agrupadas, de forma que fosse possível unir termos por sentido, por aquilo que se parecia. Os indicadores também foram selecionados conforme se encaixaram às falas das professoras.

\section{RESUltados E discusSÃo}

A seguir, serão apresentadas as informações obtidas junto aos docentes de uma escola da rede pública estadual de Santa Maria/ RS, a respeito dos mitos que envolvem os alunos com altas habilidades. Para manter a preservação da 
identidade dos sujeitos participantes da pesquisa, seus nomes foram substituídos por letras de "A" a "J".

A presentaremos cada uma das categorias e seus indicadores, que serão descritos eanal isados consi derando sua importância na desmitificação dos al unos com al tas habilidades.

\subsection{Mitos SOBRE CONSTITUIÇÃo}

Os mitos sobre constituição dizem respeito às origens das características das pessoas com altas habilidades. Assim sendo, não há uma uniformidade de opiniões entre geneticistas e ambientalistas em relação ao surgimento dessas características.

\subsubsection{As aLTAS habilidades SÃo UMA CARACTERÍSTICA EXCLUSIVAMENTE GENÉTICA (WIN NER, 1998; GUENTHER, 2000).}

Tal mito foi questionado na pergunta 7: A s pessoas com altas habilidades/ superdotadas já nascem com essa habilidade ou vai depender do meio?

Os geneticistas afirmam que as características queas pessoas com al tas habilidades apresentam seriam inatas, ou seja, elas herdariam os genes de seus familiares. A respeito desse mito as professoras entrevistadas disseram:

Professora A: “ [...] para altas habilidades acho que a criança já deveria nascer, assim, um pouquinho com QI avançado, eu acho que seria isso".

No entanto, Winner (1998, p. 119) é pontual ao afirmar que "a superdotação não pode ser inteiramente um produto do nascimento [...]".

Professora H: “ [...] eu acho que essas habilidades vêm já [...] isso vem de dentro, elejá nasce".

Entretanto, Guenther (2000, p. 53) diz que: “o potencial presente como predisposição e inclinações no plano genético, ou ao nascer, é enormemente influenciado por fatores, condições e variáveis ambientais".

A partir dessas falas é possível perceber que esse mito ainda se faz presenteno cotidiano escolar dos al unos. As palavras "nascer", "inerente" e" nato" fizeram parte do discurso das professoras, indiciando que o aluno nasceu com altas habilidades, sem cogitar-se a influência do meio ambiente durante esse processo. Assim, 50\% das professoras (A, D, G, H el) entrevistadas ainda cultivam esse mito.

3.1.2 As ALTAS HABILIDADES SÃo UMA CARACTERÍSTICA QUE DEPENDE EXCLUSIVAMENTE do estímulo ambiental (WIN NER, 1998).

Tal mito foi questionado na pergunta 7: A s pessoas com altas habilidades/ superdotadas já nascem com essa habilidade ou vai depender do meio? 
Por sua vez, os ambientalistas apontam para o meio em que o indivíduo vive, considerando-o como o único responsável pelo surgimento dessas características. Sobre esse mito, nenhuma das professoras fez menção. Diante disso, $100 \%$ das professoras desmitificaram essa concepção equivocada.

Em relação à disputa entre ambiental istas $X$ geneticistas, concorda-se quando Winner (1998, p. 136) afirma que: “nós não deveríamos concluir queal guma porcentagem das nossas habilidades são causadas por gens e o resto pelo nosso ambiente. Não deveríamos pensar sobre os genes e o ambiente operando separada e aditivamente". A ssim, sabe-se que tanto a genética quanto o meio influenciam no desenvolvimento das pessoas com al tas habilidades. Então, nossa tarefa como educadores engajados nessa causa será a de estimular as habilidades desses al unos.

3.1.3 Pais organizadores (condutores) (WIN NER, 1998 e BRASIL, 1999a).

Tal mito foi questionado na pergunta 9: 0 s pais, ao oferecerem estímulos aos seus filhos, estariam "fabricando" uma criança com altas habilidades/ superdotada?

Esse mito estaria ligado aos pais como possíveis fabricantes de filhos superdotados. Mas, como descrito anteriormente, a superdotação não pode ser fabricada. As opiniões de algumas professoras a respeito desse mito foram:

Professora B: Depende do estímulo que a gente tá dando, às vezes, a gente pode camuflar e, às vezes, dar muito estímulo e achar que é, mas não é [...].

Essa professora mostrou-se preocupada com aqueles pais que superestimulam seus filhos, sobrecarregando-os com atividades extraclasses. Ainda há aqueles pais que, por seu filho carregar o rótulo de ser superdotado, exigem que ele produza sempre em al to nível. Esse fato pode ocasionar sérios problemas, pois quando os pais ficam “[...] preocupando-se mais com as conquistas do filho do que com sua vida emocional, eles tendem a terminar com um desistente amargurado" (WIN NER, 1998, p. 245).

Criar um ambiente rico em estímulos irá contribuir para que a criança tenha acesso a informações de acordo com o interesse dela. No entanto, existem pais que obrigam seus filhos a buscarem incessantemente recursos para ampliar seus conhecimentos, quando o interesse pelo novo, pelo desconhecido, surge por parte dos pais e não do filho; há de considerar-se que esse não é o ambiente mais adequado para que uma criança se desenvolva.

Professora C: "Poderiam, eu acho que a mai oria dos pais tem essa ansiedade hoje em dia, a criança já não vive mais a infância de brincar com brinquedos, correr [...] então os pais começam a colocar em tudo e já fabricam um filho diferente. [...] então, eles podem estar fabricando uma criança superdotada".

Professora F: “Eu acho que sim, eu acho que pode, eu acho que daí os pais estão colaborando para isso".

A pós analisarmos as respostas das professoras, 20\% (professoras C e F) concluíram que os pais, ao oferecerem estímulos aos filhos, podem estar 
fabricando uma criança com altas habilidades, e $80 \%$ acham que os pais podem auxiliar com o estímulo, mas o interesse deve partir da criança.

\subsection{Mitos SOBRE A DISTRIBUIÇÃO}

Esses mitos dizem respeito às Pessoas com al tas habilidades como uma característica com incidência maior ou exclusiva em certas parcelas da população (classes privilegiadas, homens...), quase inexistente na população geral.

\subsubsection{As Pessoas com Altas Habilidades provêm de classes socioeconômicas PRIVILEGIADAS (BRASIL, 1999a)}

Tal mito foi questionado na pergunta 8: 0 meio social em que a criança nasce e se desenvolve favorece para que ela seja uma pessoa com altas habilidades/ superdotada?

Essemito podeestar relacionado com o senso comum demuitas pessoas que acreditam que um indivíduo pode ser superdotado somente se provier de família com posses, que assim terá condições de investir financei ramente em seus filhos. Sobre esse mito, as professoras relataram que:

Professora A: Eu acho que o meio social favorece muito a criança. [...] a gente vêos alunos que os pais têm até a 2ª série, eles não estão lendo ainda, não têm o uso do livro, do computador, do jornal em casa.

No entanto, essa concepção apresentada por $40 \%$ das professoras ( $A$, B, C e F) entrevistadas, mostra-se equivocada, pois a superdotação "pode evidenciar-se em qualquer nível, independente de idade, sexo, raça, credos e, sobretudo, qualquer nível socioeconômico" (BRASIL, 1999a, p. 160). Para tanto, esses al unos de classes menos favorecidas necessitam ser identificados, para quea família, em conjunto com a escola, busque ações que favoreçam a estimulação e o desenvolvimento dessas crianças. Como exemplifica a professora E:

[...] se o problema fosse o da condição econômica restrita, acho que entra o papel da escola em descobrir, e tentar proporcionar a ela condições para que ela possa atingir..., porque hoje, infelizmente tudo gira em torno da questão econômica.

\subsection{Mitos SOBRE IDENTIFICAÇÃo}

Esses mitos remetem para a discussão entre vantagens $X$ desvantagens da identificação das pessoas com altas habilidades.

\subsubsection{Não se deVe identificar as Pessoas com Altas Habilidades (A Len CAR, 2001)}

Tal mito foi questionado na pergunta 3: V ocê considera importante identificar um aluno com al tas habilidades/ superdotado? 
Ora, se essas pessoas não forem identificadas como terão suas necessidades educacionais atendidas? Então, é de suma importância que os professores saibam como reconhecer esses alunos para poderem encaminhá-los a um atendimento especializado. Vejamos as respostas das professoras:

Professora A:"Olha, não sei, se é para destacar dos demais eu acho que não é conveniente destacá-los, eu acho que não se for um superdotado.

A partir dessa fala pode-se perceber que os alunos com altas habilidades, muitas vezes, não são considerados pessoas com necessidades educacionais especiais. Os deficientes são encaminhados para uma avaliação, para um posterior atendimento especializado, despertando, por parte da sociedade, sentimentos como piedade; mas o al uno superdotado é visto de forma antagônica no queser efereao encaminhamento para aval iação deuma possível al ta habilidade. Diante desse caso, os profissionais usam do discurso de que esse al uno apresenta uma inteligência acima da média dos demais colegas (e até da professora), não necessitando de um atendimento especializado, o que poderia causar sentimentos el itistas por parte dos alunos identificados. Pérez (2003, p. 51-52) exemplifica essa situação: "os próprios mitos e crenças em relação a estas pessoas fazem que a identificação seja considerada uma rotulação e que ela seja vista como uma discriminação dos indivíduos identificados que, no imaginário popular, passam a ser melhores que o resto da sociedade".

Professora B: Eu acho importante, sim, porque nós corremos o risco de deixálos frustrados, porque eles têm uma energia, eles têm uma potência, eles têm alguma coisa para colocar para fora e não sabem como nem como canalizar aquilo ali [...].

A professora B levantou uma questão muito importante, a canalização da energia, pois:

Sefor feito um balanço realístico dos maiores problemas atuais da humanidade, passando necessariamente pelo narcotráfico, corrupção, terrorismo, crime organizado, exploração de pessoas egrupos marginalizados, vamos encontrar, com toda certeza, uma grande quantidade detalento humano investido nessas atividades (GUENTHER, 2000, p. 17).

A partir disso, é preocupante a negligência que alguns profissionais da área educacional adotam em relação à identificação dos alunos com altas habilidades.

A nalisando as respostas das professoras, vê-se que apenas uma (professora A - 10\%) acha que a identificação traria conseqüências negativas para o aluno com al tas habilidades.

\subsection{MITOS SOBRE DESEMPENHO}

Esses mitos estão associados ao aluno com al tas habilidades como tendo que ser uma pessoa competente em todas as áreas do currículo escolar. 


\subsubsection{A PAH SE DESTACA EM TODAS AS ÁREAS DO CURRÍCULO ESCOLAR, TEM QUE TER BOAS NOTAS. É O ALUNo NOTA 10 Em tUdo (ALENCAR; FLEITH, 2001; BRASIL, 1999a e EXTREMIANA, 2000)}

Tal mito foi questionado na pergunta 1: Como você definiria/descreveria um aluno com altas habilidades/ superdotado?

Quando as professoras foram questionadas sobre quem seria o aluno com altas habilidades, obtivemos as seguintes respostas:

Professora A: [...] rendimento ótimo tudo 100, tudo 10 em trabalhos, Matemática, cálculo, em tudo, interpretação, eu acho que seria tudo na base do 100. [...].

ProfessoraE: Em relação ao rendimento deveria ser um al uno nota dez sempre.

Diante disso, Alencar (2001, p. 126), diz que:

Outra idéia também disseminada é a de que o superdotado apresentará necessariamente um bom rendimento na escola. Isso, entretanto, nem sempre acontece. Muitas vezes, observa-se uma discrepância entre o potencial (aquilo que a pessoa é capaz de realizar e aprender) e o desempenho real (aquilo que o indivíduo demonstra conhecer).

Assim, diversos fatores contribuem para que o aluno com altas habilidades possa, realmente, ter um bom rendimento escolar. Entre eles, podemse citar: aulas motivadoras, dinâmicas, o que irá depender da metodologia que o professor utilizar, por exemplo, grupos de discussões, ao invés de aulas somente expositivas.

Professora D: U ma criança que se sobressaísse em conhecimentos em relação aos outros da turma, um conhecimento muito além daquele que os outros têm.[...] na maioria das vezes eles são bastante participativos, atuantes, eles exemplificam bastante na aula, e por vezes até perturbam por saber mais, e têm os fraquinhos que não acompanham ea gentetem que ser mais lenta com os outros. Perturbam porque têm mais conhecimento, mais base, então a aula se torna fácil para eles.

Sobre essa fala podemos nos reportar a Extremiana (2000, p. 215):

El maestro, con sus clases masificadas, no tiene tiempo para dedicar una atención preferente al pequeño superdotado. D urantelas horas de clase se aburre y bosteza. LoS trabajos que están realizando afanosamente sus compañeros, él hace tiempo que los ha terminado. ¿ Q uéotra cosa puedehacer? Sól o lequedan dos alternativas: una es perderse por las nubes y volar hacia situaciones más gratificantes, y la otra - la más socorrida es dedicarse a incordiar o distraer al vecino de pupitre ${ }^{7}$.

\footnotetext{
7 Tradução livre: “O professor, com suas salas de aulas massificadas, não tem tempo para dedicar atenção preferencial ao pequeno superdotado. Durante as horas de aula se aborrece e boceja. Os trabal hos que estão realizando afanosamente seus colegas, há tempos ele já tinha terminado. Que outra coisa pode fazer? Só Ihe restam duas alternativas: uma é perder-se pelas nuvens e voar para situações mais gratificantes, e a outra, a mais empregada, é dedicar-se a incomodar ou distrair seu vizinho de classe".
} 
Com uma sala de aula superlotada, muitos professores acabam por atender os alunos medianos, e resta ao al uno com altas habilidades ficar sozinho com seus pensamentos, voando, ou então incomodar colegas, atirando papéis, caminhando de um lado para outro, fazendo questionamentos ao professor sobre outros assuntos, que certamente são do interesse del e e não correspondem ao que o professor está ensinando.

A partir desses relatosfoi possível verificar queo esteriótipo equivocado do aluno com altas habilidades como sendo aquele que se destaca em todas as matérias, com rendimento dez em tudo persiste na concepção de três professoras (A, E, H - 30\%).

\subsection{Mitos SOBRE CONSEQÜÊNCIAS}

Esses mitos apóiam-se nas conseqüências advindas dos comportamentos dos alunos com altas habilidades, ou seja, eles são vistos como possíveis doentes mentais, como aqueles que terão sucesso profissional garantido, que são auto-educáveis, etc. Assim, tais mitos prejudicam, ainda mais, a identificação e o atendimento desses alunos, já que são vistos como autodidatas.

3.5.1 Crianças com altas habilidades Serão adultos eminentes (WIN NER, 1998; GUENTHER, 2000; BRASIL, 1999a; ALEN CAR \& FLEITH, 2001)

Tal mito foi questionado na pergunta 10: 0 que você espera de um aluno com altas habilidades/superdotado quando el e for adulto?

Vejamos as respostas das professoras:

Professora J: Se ele é superdotado em al guma coisa ele é por si só.

Essa professora se refere à superdotação como sendo uma condição existencial que independe do que vir pela frente. No entanto, como pontua Guenther (2000, p. 115):

[...] dotação éal go que o indivíduo tem consigo, etraz em potencial ao nascer, mas cujo desenvolvimento e concretização será trabal hada e conseguida durante a vida, nas interações que a pessoa estabelece processual mente com seu ambiente físico, psicológico e social.

Logo, não basta ser uma pessoa com al tas habilidades para, no futuro, ter sucesso profissional garantido. Mas, se for estimulada a desenvolver sua área de domínio, há maiores probabilidades de que isso venha a acontecer.

Professora I: Não sei te dizer se el e vai se sobressair em relação aos outros no futuro. Só se ele for estimulado e trabal hado. E, se não for trabalhado neles essas habilidades, como o trabalho que vocês fazem ${ }^{8}$, de repente parem. A gente não sabe até que ponto eles vão se sobressaindo.

\footnotetext{
${ }^{8}$ Esta professora fez menção ao PIT - Programa de Incentivo ao Talento, que é um programa de enriquecimento que atende crianças com características de al tas habilidades que freqüentam de $1^{\mathfrak{a} a}$ a 5 a série do ensino fundamental de escolas da rede pública e privada de Santa Maria/ RS.
} 
A partir do relato dessas duas professoras, percebe-se que há uma preocupação em relação ao futuro dos al unos com al tas habilidades. "M uitos deles, em função de características do próprio contexto familiar, educacional e social, apresentam apenas um desempenho medíocre e, mesmo, abaixo da média" (ALENCAR, 2001, p. 126). Dessa forma, a escola deve ter a preocupação em estimular os al unos com al tas habilidades e incentivá-los a buscarem uma carreira profissional que possa vir ao encontro das necessidades econômicas, bem como abranger a área de interesse desses alunos.

Por fim, apenas uma professora ( $-10 \%$ ) concluiu que basta ser uma pessoa com al tas habilidades para, no futuro, ter garantia de que seu talento não se altere nem para mais, nem para menos.

3.5.2Tudo é fácIL PARA A PAH (BRASI L, 1999a, EXTREMIANA, 2000eWIN NER, 1998)

Tal mito foi questionado na pergunta 4: “É possível um aluno com altas habilidades/superdotado ter um al to conhecimento em determinada área e um déficit em outra?"

Esse mito refere-se ao al uno com altas habilidades como um ser dotado de uma enorme facilidade para a aprendizagem, contudo, como já salientado anteriormente, essas crianças podem obter um baixo rendimento escolar, inclusive déficits de aprendizagem na área que não é do seu domínio. Sobre tal mito as professoras disseram que:

Professora A: Eu acho que superdotado é aquele que domina tudo, se é superdotado é bom em tudo.

Professora D: Em todas as áreas, já por elas serem superdotadas eu acho que elas sabem mais.

Contudo, a literatura é clara ao afirmar que "as crianças podem até ser superdotadas em uma área acadêmica eapresentar distúrbio de aprendizagem em outra" (WIN NER, 1998, p. 15). Assim, o professor deveser esclarecido sobre o fato de que o al uno com altas habilidades pode ter, sim, um déficit ou dificuldade de aprendizagem na área que não é do seu interesse. Muitas vezes, os professores acabam não identificando os alunos que apresentam uma alta habilidade na área criativo-produtiva, já que a escola tem uma tendência a valorizar mais a área acadêmica. Isso porque, de acordo com Extremiana, “[...] normalmente, y debido a las expectativas ester eotipadas del profesorado, se considera que los al umnos superdotados han de mostrar un rendimiento escolar global"9 (2000, p. 170-171). Sendo assim, o professor que se baseia apenas em notas para selecionar o aluno com altas habilidades estará privando os demais alunos que apresentam habilidades para áreas como música, artes e teatro, dentre outras.

\footnotetext{
${ }^{9}$ Tradução livre: “[...] normalmente, e devido às expectativas estereotipadas dos professores, se considera os alunos superdotados como tendo que manifestar um rendimento escolar global".
} 
Sobre esse mito, quatro professoras (A, D, E e H - 40\%) acham que, para ser um aluno com altas habilidades, ele deve ser bom em tudo, destacar-se em todas as áreas do currículo.

\subsection{Mitos SOBRE ATENDIMENTO}

A legislação prevêatendimento especializado para os alunos com al tas habilidades. O desconhecimento por parte da comunidade escolar é um dos empecilhos que faz com que esse atendimento não se torne efetivo.

\subsubsection{As PESSOAS COM ALTAS HABILIDADES NÃO PRECISAM DE ATENDIMENTO EDUCACIONAL ESPECIAL: (ALENCAR, 2001 e EXTREMIANA, 2000)}

Tal mito foi questionado na pergunta 6: Para você, seria importante que um aluno com al tas habilidades/superdotado tivesse um aten dimento especializado?

Esse mito está ligado à idéia de que o al uno com al tas habilidades não apresenta necessidades educacionais especiais, logo não precisa de um atendimento especializado.

Professora A: Olha, não sei se seria o caso, porque eu acho que a gente deveria pôr a criança na escola com sete anos, que nem aquele dos Estados Unidos com catorze anos estava fazendo curso superior, aquele sim era superdotado então eu acho quetem queir devagar com essas crianças, não adianta tu correr eles, a maioria deles não tem maturidade.

Ao mesmo tempo que essa professora acha que tais al unos não devem ter um atendimento especializado e devem entrar na escola com sete anos, ressalta que aquele adolescente dos Estados Unidos, por já estar cursando uma universidade, é uma pessoa com altas habilidades. Assim, para a professora A, a precocidade é vista como sinônimo de superdotação, mas ao mesmo tempo acha que não se deve pôr uma criança na escola antes dos sete anos.

Muitas das estratégias para reconhecimento do talento na infância apontam para a precocidade como um dos sinais significativos. Mas, curiosamente, os estudos e pesquisas na área nos revelam que menos de um terço das pessoas produtivas e mais capazes não foram precoces (GUENTHER, 2000, p. 34).

Assim sendo, o interesse e a busca pel o desconhecido, o interesse por uma atividade desde pequeno deveser considerado como um indicativo para uma possível alta habilidade.

Quanto ao atendimento, apenas a professora A (10\%) acha que não seria o caso mais adequado devido à precocidade desses alunos.

Ao finalizar a análise de conteúdo sobre os mitos que envolvem os alunos com altas habilidades, obtivemos os seguintes resultados: 


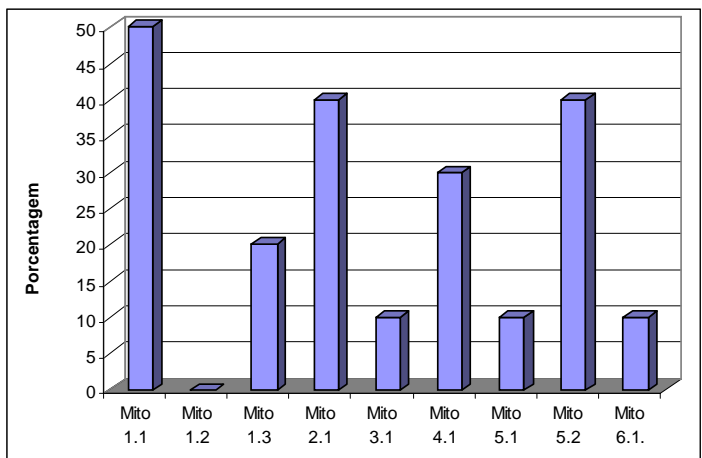

Figura 1 - Porcentagem da incidência dos mitos.

Observando a Figura 1, é possível visualizar a incidência com que os mitos foram mencionados pelos sujeitos da pesquisa. Assim, constata-se que a maioria das professoras já desmitificou seus conceitos sobre os alunos com altas habilidades. Observa-se, que sobre o mito 1.1 - que obteve maior incidência, 50\% - a metade das entrevistadas ainda têm a concepção errônea de queas al tas habilidades são uma característica exclusivamente genética. Já o mito 1.2 não foi apontado por nenhuma das professoras, sendo que, assim, 100\% delas desmitificaram esta concepção: As altas habilidades são uma característica que depende exclusivamente do estímulo ambiental.

Em relação à incidência dos mitos nas entrevistas de cada professora, verificamos que: das dez participantes, a professora A podeser observada em $60 \%$ dos mitos citados, as demais não ultrapassaram a 20\%, conforme representado na Figura 2.

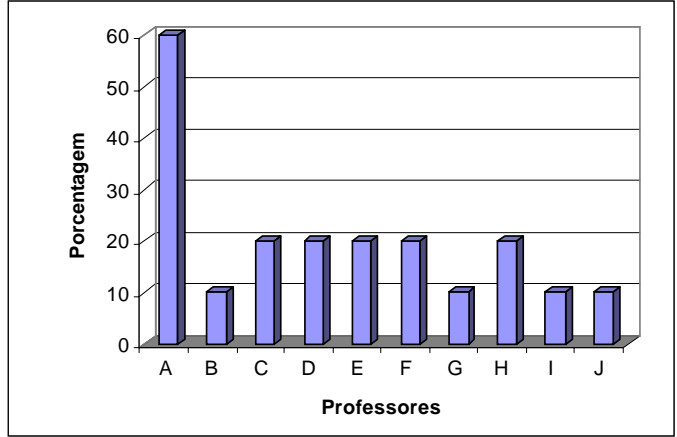

Figura 2 - Incidência dos mitos nas respostas das professoras.

Esse fato pode ser explicado, pois essa professora não participou da pesquisa desenvolvida na escola nos anos de 2002 e 2003. Inclusive, enquanto as demais professoras indicaram alunos com características de altas habilidades, ela nem devolveu o questionário solicitado para avaliar os alunos. 


\section{CONSIDERAÇõEs FINAIS}

A pós finalizar esta pesquisa, percebemos o quanto a informação sobre quem é o aluno com altas habilidades auxilia na sua identificação como pessoa com necessidades educacionais especiais.

Com base nos mitos analisados, foi possível constatar que a formação continuada dos professores é algo que deve estar presente no dia a dia desses profissionais. Assim, concluímos que os objetivos propostos por essa pesquisa foram alcançados, pois verificamos que a maioria dos docentes, da escola que participou da coleta dos dados, desmitificou suas concepções sobre o al uno com altas habilidades. Ainda, a professora que mencionou os mitos com maior freqüência em sua fala não havia participado ativamente do projeto desenvolvido em anos anteriores nessa escola.

Nessa perspectiva, verificamos o quanto é importante informar e conscientizar os professores sobre a identificação e o encaminhamento de um atendimento especializado para os alunos com al tas habilidades. A creditamos que essa pesquisa comprovou tal fato, já que a maioria das professoras não vêo aluno com altas habilidades como o sabe-tudo, al to rendimento em todas as disciplinas, arrogante, metido, CD F , entre tantos outros rótulos que permeiam o cotidiano escolar desses alunos.

\section{RefERÊnCIAS}

ALENCAR, E. S.; FLEITH, D. de S. Superdotados: determinantes, educação e ajustamento. 2. ed. São Paulo: EPU, 2001.

ALENCAR, E. S. Criatividade e educação de superdotados. Petrópolis: Vozes, 2001.

BA RDIN, L. A nálise de conteúdo. Lisboa: edições 70, 1977.

BRASIL, Ministério da Educação, Secretaria de Educação Especial. D iretrizes N acionais para a Educação Especial na E ducação Básica. Brasília: MEC/ SEESP, 2001.

. Programa de capacitação de recursos humanos do ensino fundamental: superdotação e talento. Brasília: MEC/ SEESP, Vol I, 1999a.

. Programa de capacitação de recursos humanos do ensino fundamental: superdotação e talento. Brasília: MEC/ SEESP, Vol II, 1999b.

. D iretrizes gerais para o atendimento educacional dos al unos portadores deal tas habilidades/ superdotação e tal entos. Brasília: MEC/ SEESP, 1995a.

- Subsídios para organização e funcionamento de serviços de educação especial: área de altas habilidades. Brasília: MEC/ SEESP, 1995b.

EXTREMIANA, A. A. N iños superdotados. Madri: Pirámide, 2000.

FERREIRA, A. B. de H. Dicionário A urélio Eletrônico século XXI: português/ português. Autoria do software Márcio Ellery Girão Barroso. Versão 3.0, Editora N ova Fronteira e Lexikon Informática, novembro de 1999. 
RECH, A. J. D.; FREITAS, S. N.

GUENTHER, Z. C. D esenvolver capacidades e talentos: um conceito de inclusão. Petrópolis: Vozes, 2000.

LÜDKE, M.; ANDRÉ, M. E. D. A. Pesquisa em educação: abordagens qualitativas. São Paulo: EPU, 1986.

MINAYO, M. C. deS. (org). Pesquisa social: teoria método ecriatividade. 17. ed. Petrópolis: Vozes, 2000.

PÉREZ, S. G. P. B. M itos e crenças sobre as pessoas com al tas habilidades: al guns aspectos que dificultam o seu atendimento. Cadernos de E du cação Especial, v. 2, no 22, p. 45-59, 2003.

RUSS, J. D icionário de filosofia. São Paulo: Scipione, 1994.

TRIVIÑOS, A. N. S. Introdução à pesquisa em ciências sociais: a pesquisa qualitativa em educação. São Paulo: Atlas, 1987.

WINNER, E. Crianças superdotadas: mitos e realidades. Tradução de Sandra Costa. Porto Alegre: Artes Médicas, 1998.

Recebido em 11/ 05/ 2005

Reformulado em 25/ 08/ 2005

A provado em 30/ 08/ 2005 